\title{
The Impact of China Exchange Rate Policy on its Trading Partners: Evidence Based on the GVAR Model
}

\author{
Shah ABBAS ${ }^{1}$, Van Chien NGUYEN ${ }^{2}$, Zhu YANFU ${ }^{3}$, Huu Tinh NGUYEN ${ }^{4}$
}

Received: May 26, 2020 Revised: June 07, 2020 Accepted: July 09, 2020

\begin{abstract}
This study is designed to investigate the impact of China exchange rate policy on its trading partners by using a country multi-dataset GVAR model. Our model includes samples of 30 countries, six from high-income, six from middle-income and eighteen from low-income countries. This study used annual time series data over the period 1992 to 2017 . We constructed currency misalignment index and it provided some interesting features about the currency undervaluation and overvaluation. The results of the currency misalignment shows that China's Renminbi is structurally more undervalued over the sample period as compared to other countries, and fluctuation in major currencies effects the global trade around the world. The overall empirical results of the GVAR model indicate that RMB undervaluation affects the trade pattern and macroeconomic performance of China's trading partners. Overall, China's exchange rate undervaluation has mixed effects on trading partner's GDP, exports and imports. The devaluation of China's RMB efficiently stimulated China's exports and reduced imports. While, in some countries, this effect is reverse, the RMB undervaluation increases the GDP of partner countries and also increases their exports to China. The results confirm the strong and leading role of the Chinese Renminbi in the global trade.
\end{abstract}

Keywords: Exchange Rate Policy, Currency Misalignment, GVAR Model, Generalized Impulse

JEL Classification Code: C32, E30, F36, Q37

\section{Introduction}

Since the 2000s, the exchange rate policy has been one of the controversial aspects of international macroeconomics. Studies indicate that the exchange rate plays an important role in country trade performance. Fluctuation in the exchange rate has important repercussions on international trade, on balance of payment, and overall macroeconomic performance. In the case of China, the extraordinary increase in Chinese economic growth, trade surplus and

${ }^{1}$ First Author. PhD Candidate, School of Economics, Zhongnan University of Economics and Law, Wuhan, China. Email: shahabbas_14@pide.edu.pk

${ }^{2}$ Corresponding Author. Department of Banking and Finance, Faculty of Economics, Thu Dau Mot University, Binh Duong, Vietnam [Postal Address: No. 6 Tran Van On Street, Thu Dau Mot, Binh Duong, 590000, Vietnam] Email:chiennv@tdmu.edu.vn

${ }^{3}$ Professor, School of Economics, Zhongnan University of Economics and Law, Wuhan, China. Email: zhuyanfu@126.com

${ }^{4}$ Thu Dau Mot University, Vietnam. Email: tinhnh@tdmu.edu.vn

(c) Copyright: The Author(s)

This is an Open Access article distributed under the terms of the Creative Commons Attribution Non-Commercial License (http://Creativecommons.org/licenses/by-nc/4.0/) which permits unrestricted noncommercial use, distribution, and reproduction in any medium, provided the original work is properly cited. high revenues from foreign direct investment have opened the debate among academics, policymakers and research scholars about its impact on the global trade balance. A number of empirical studies show that persistent increase in economic growth is a result of an increase in exports along with undervaluation of the Chinese RMB exchange rate relative to the equilibrium value (Bitans, 2004; Rodrik, 2006; Cline \& Williamson, 2011; Gangnes et al., 2014). The option of Chinese authorities for maintaining the currency below its equilibrium value has been a growing concern and numerous controversy subjects within the international community with regard to international trade.

Historically, China's economy advanced through the process of reforms, and a centralized exchange rate controlled mechanism prevailed in 1970 . The dual exchange rate system was introduced in 1985. The first one is the official exchange rate for commercial transactions and the second is for noncommercial transactions. The managed float exchange rate system was enforced from 1986 to 1994, while Chinese authorities decided to index its currency to the US dollar in 1994. The Asian crisis breakout in 1997 and Chinese monetary authorities decided to fix the exchange rate against dollar 8.28 per US dollar. This decision remained until 
July 2005. The international community pressured China monetary authorities as the Bank of China (BOC) allowed the appreciation of the Renminbi against the US dollar by about $2 \%$. The Chinese monetary authorities announced that the county would adopt a managed floating exchange rate system based on the basket of currencies. However, this decision introduced the possibility of greater flexibility in exchange rate relations to the main currencies of the world economy and the Chinese Renminbi.

The United Nations and the European Union argued that fixed and artificially-revalued exchange rates have a negative impact on the competitiveness of North American and European Exports. They pressured China and the International Monetary Fund to play a crucial role in the decision of China's monetary authority (Choi et al., 2018). In these circumstances, Chinese monetary authorities have appreciated their currency by $18.6 \%$ in real effective terms and $16 \%$ in nominal terms against the US dollar during 2005-2008. However, with the financial crisis of 2008-09 in the US, once again the Chinese Renminbi exchange rate has been frozen against the US dollar (Cline \& Kim, 2010). The surplus in the current account and fixed exchange rate (6.23) system against the US dollar placed China at the center of the debate among the policymakers, academics, and social scientists. The main objective of practicing fixed exchange rate policy in China is to increase the exports and desire to maintain internal and regional macroeconomic stability and avoid the inflationary pressure. This study aims to investigate the impact of China's exchange rate policy on its trading partners by using the global vector autoregressive (GVAR) methodology.

This study is different from previous studies in several aspects. First, this study used both domestic and international variables to estimate the GVAR model for 30 major trading partners of China. Second, this study constructs the currency misalignment undervaluation index, which is more helpful to investigate the impact of exchange rate undervaluation on other countries. Apart from the introduction, this study is organized into five sections. The second section presents the most relevant theoretical and empirical literature on exchange rate fluctuations and their impact. The third section describes empirical model and data. The fourth section provides an empirical results and discussion. The fifth section concludes and draws policy implications.

\section{Literature Review}

Traditionally, macroeconomic and international trade theories explain the dynamic linkages between exchange rate and international trade flows. An appreciation or depreciation of currency is associated with either a decrease or an increase in trade flows. Theoretical and empirical evidence strongly support the idea that movement in the exchange rate has an important impact on macroeconomic variables, especially on trade follows. The devaluation or depreciation of currency makes exports cheaper and imports costlier, and both have direct and indirect impact on the international trade (Leamer, 1980; Montiel \& Ostry, 1991). For example, an appreciation of the exchange rate leads to the demand for more imports and reduced supply of exports by increasing the value of the domestic currency in the international market. According to Marshal Learner, the devaluation of domestic currency leads to an improvement in trade balance when the sum of the absolute value of export and import price elasticity is greater than unity (Thanh \& Kalirajan, 2005). On the other hand, in case of a large trade deficit and fewer exports, this will not happen.

Péridy (2003) examined the impact of exchange rate volatility on exports of G-7 countries. He argued that the impact of exchange rate volatility varies considerably depending on the industry covered and the destination of the market. He found a negative impact of exchange rate volatility, but for several countries and sectors, the findings are not statistically significant. Similarly, Byrne et al. (2008) studied the impact of exchange rate volatility on bilateral US trade using sectorial data. They found that exchange rate volatility is negative and statically significant across sectors. Bahmani-Oskooee and Harvey (2011) looked at the impact of exchange rate volatility on US trading partners. They found that exchange rate volatility has adverse effects trade in the short-run and it is ambiguous in the long run.

The exchange rates have always been a sensitive subject (Lamy, 2012) in international trade due to their relations with more than one source. First, the exchange rate is an endogenous variable that results from the complex interaction of macroeconomic, financial and trade determinants. But, from the perspective of an individual trader, currency movement is exogenous. Second, uncertainty and cost associated with exchange rate fluctuation may be a reason for the frustration of producer. The deviations from the level and volatility often impose a cost on the real economy that is asymmetric depending on different types of producers and economies. Third, Irwin and Sanders (2011) found that international trade and monetary relations have certainly undergone more than one period of tension in the course of history. The most relevant example is the recent financial crisis the period of distress for the world economy, the exchange rate is perceived to be a transmission belt of financial shocks to the real economy and vector of monetary dumping. Empirical studies stress that exchange rate valuation or undervaluation has a closed relationship with global trade imbalance (Brender \& Pisani, 2010; Blanchard \& Milesi-Ferretti, 2012). More precisely, exchange rate misalignment damages the economy and caused subprime crises among the industrial countries. This can increase the probability of currency war among the industrial and latter between emerging countries (Cline \& Kim, 2010). 
However, the debate about the exchange rates and their impact on trade has been shifted from exchange rate volatility to appreciation or depreciation and currency misalignment during the first decades of the 21 st century, and in the aftermath of the global financial crisis. The currency misalignments affect international trade through two broad direct channels. The first is price signals that may have an immediate impact on trade patterns. The second is currency misalignment that changes the decision of investors and causes a shift in resources between non-tradable and tradable sectors in the economy (Eichengreen et al., 2007; Rodrik, 2008). However, these direct effects depend on the number of factors that economic theory has helped spell out. The standard economic theory defines that in the long run, all prices are fully flexible. In the case of the short run, it is different because of prices in the economy need time to adjust to any policy change.

The movement in the nominal exchange rate can alter relative prices and allocation of resources between tradable and non-tradable goods and international trade flows (Krugman \& Obstfeld, 2009). Accordingly, nominal depreciation of home currency causes real depreciation of the exchange rate, which signifies that foreign goods are more expensive and consumers buying domestic products and counties have exported more because foreign consumers switch to expensive goods. On the other hand, currency depreciation causes domestic economies to import less. This implies that the result of currency depreciation causes to import less and export more (Blanchard \& Milesi-Ferretti, 2009). Several studies show some common patterns in the relationship between exchange rate volatility, misalignment and trade flows. The trade channel of exchange rate link changes in exchange rates to export and import volumes via the prices of trade goods, if export prices are fixed in domestic currency than the effect of exchange rate depreciation will pass through to lower export prices as measured in the foreign currency. Foreign demand for exports typically increases as their foreign currency prices fall, and so depreciation will raise the export volume and leads to a lower volume of imports.

Greenaway et al. (2010) studied the relationship between exchange rate and exports and imports. They show that UK manufacturing firms face a negative impact of exchange rate appreciation on the probability to exports, which are lower in industries that import a greater share of inputs. A depreciation or devaluation of domestic currency stimulates economic activity through initially increase the price of foreign goods relative to domestic goods. The demand for foreign goods is switching, increasing the demand for domestic goods and it promotes trade balance as well as meets additional demand in the economy. So, currency depreciation lowers export prices and increases the import prices (Frankel \& Rose, 2000; Mukherjee \& Pozo, 2011; Zhang, 2012).
Auboin and Ruta (2013) investigate the relationship between exchange rate and trade. They investigated two main issues: the first is the impact of exchange rate volatility and second is the impact of exchange rate misalignment on international trade flows. Accordingly, exchange rate volatility has a negative impact on trade. They argued that this impact depends on a number of factors, including the existence of hedging instruments, the structure of production, and the degree of integration across the countries. On the other hand, for the second issue, they found that exchange rate misalignments have a short-run impact on the model based on the price rigidities. Furthermore, they extend this argument; it depends on the number of instruments like the price strategy of the firms engaging in international trade and participation of a country in the global production network. The trade effect of currency misalignment is disappearing in the long run.

Hooy and Baharumshah (2015) investigated the impact of exchange rate volatility on trade performance of East Asian economies. They found that currency volatility has a less negative impact on trade performance. Contrary to it, Hooy et al. (2016) found a significant negative impact of exchange rate volatility on trade performance of ASEAN countries. Accordingly, the exchange rate volatility has only an impact on high tech and medium-tech exports.

\section{Model Specification and Data}

\subsection{Model Specification}

We propose a global vector autoregressive model (GVAR) based on the annual data for major trading partners of China. The GVAR approach is purely suitable for this research, it allows us to capture cross-sectional dependencies between countries. Technically, GVAR is a global model that connects the vector autoregression (VAR) model of each country, where foreign variables are associated with domestic variables of the specific countries through trade and financial markets. The global vector autoregressive (GAR) model was developed originally by Pesaran et al. (2004) to study the issues of international trade adjustment. This model was developed especially for the growing interconnections and interdependencies between international and national factors in the financial market and risk management analysis. It is also consistently used to assess the impact of one big economy on other smaller economies as well as on the whole global economy (Feldkircher \& Korhonen, 2014; Inoue et al., 2015; Cashin et al., 2017).

Our GVAR model is estimated with the full sample of the top 30 countries, of which six are lower middle-income countries, sixare upper middle-income countries, and 18 are high-income countries. The selection 
of those countries is based on the World Integrated Trade Solution (WITS) 2017 import and export data. Our country-specific (VAR-X) model includes four domestic variables, including real GDP $\left(y_{i t}\right)$, currency misalignment $\left(\right.$ miss $\left._{i, t}\right)$, exports $\left(\exp _{i, t}\right)$, and imports $\left(i m p_{i, t}\right)$ of goods for each country disaggregated by the origin and destination for other $\mathrm{j}$ countries and one global variable given by the world oil prices $\left(\mathrm{POil}_{i, t}\right)$. The general specification for each country-specific vector of the domestic variable is

$$
\begin{aligned}
& x_{i t}=\left(y_{i t}, \text { miss }_{i, t}, \exp _{i, t}, \operatorname{imp}_{i, t}\right) \\
& x_{i, t}^{*}=\left(y_{i, t}^{*}, \text { miss }_{i, t}^{*}, \exp _{i, t}^{*}, \operatorname{imp}_{i, t}^{*}, \text { POil }_{i, t}\right)
\end{aligned}
$$

We followDees et al. (2007) as we include world oil prices as an endogenous variable in the China model. The endogeneity of world oil prices reflects the dominant role of China's economy in global trade. Similarly, currency misalignment is also included as an endogenous variable in the model to capture the trade imbalance in the global economy. The China model is set $\mathrm{i}=0$, we have

$$
x_{0 t}=\left(y_{0 t}, m i s s_{0 t}, \exp _{0 t}, i m p_{0 t}, P O i l_{o t}\right)
$$

Where POil $_{o t}$ is world oil prices. The foreign counterpart of these variables are given as follows

$$
\begin{aligned}
& x_{i, t}^{*}=\left(y_{o t}^{*}, m i s s_{0 t}^{*}, \exp _{0 t}^{*}, i m p_{0 t}^{*}, P^{\prime} O i l_{0 t}\right) \\
& i \in\{1, \ldots \ldots \ldots \ldots . . . N-1\}
\end{aligned}
$$

The foreign variables are constructed using trade weight which are defined as a weighted average of each trading partner country.

$$
x_{i, t}^{*}=\sum_{j=0}^{N} w_{i, j} x_{j} \quad w_{i, i}=0
$$

With $w_{i, j}, \mathrm{j}=0,1 \ldots \ldots, \mathrm{N}$ stand for the weights such that $\sum_{j=0}^{N} w_{i, j}=0$

More specifically, we use time-varying trade shares of a foreign country in total exports and imports across the whole period. In order to test the exogeneity, we used the method proposed by Johansen (1992) and Johansen et al. (1998). The weak exogeneity test is the F-test hypothesis that $r_{i j}=0$ for each $j=1,2 \ldots \ldots . r_{i}$. The results show in table 3 , it is suggested that the weak exogeneity hypothesis could not be rejected for most of the variables, only 6 out of 150 tests performed to reject the weak exogeneity hypothesis.

\subsection{Data}

The data for the current study were taken from the World Bank development indicators (WDI), International Financial Statistics (IFS) and World Integrated Trade solution (WITS). The data on GDP (constant $=2010)$ and world oil prices were taken from the WDI, import and export data were taken from the WITS, and real exchange rate data were taken from the IFS. Currency misalignment index: Currency misalignment is measured through two approaches in the literature. The first is a deviation from the equilibrium exchange rate; the second approach is to regress the real exchange rate at purchasing power parity (PPP) on real per capita GDP. We, then, measure the difference between the log of the real exchange rate at PPP and log of fitted values form regression(Rodrik, 2008; Freund \& Pierola, 2012). In this study, we used the second approach to measure currency misalignment. The positive values are considered currency overvaluation misalignment and negative values are considered currency undervaluation. The real exchange rate at PPP (2011) is taken from the international financial statistics (IFS).

\section{Empirical Results}

\subsection{Unit Root Test}

In order to estimate the country-specific model we follow the method of Pesaran et al. (2004) and Dees et al. (2007), that all the country-specific variables are I(1), the country-specific exogenous variables are weakly exogenous, and the model is stable over time. The order of integration can allow us to distinguish between long-run and short-run relation. We begin by examining the integration properties of individual series. The Augmented Dickey-Fuller (ADF) unit root test is used to the order of integration as shown in Tables 1 . The ADF test shows all the variables are stationary at first difference.

Then, we proceed with the country-specific model and check lag length based on the appropriate criteria for domestic and foreign variables as well as cointegrating rank. Due to the data limitation, we empirically analyze by setting a leg length of 3 for endogenous variables $\left(q_{i}=3\right)$ and one for weakly exogenous variables $\left(q_{i}=1\right)$. Table 2 shows the selection of lag length and cointegrating vectors. The choice of lag length was based on AIC and BIC criteria. The rank of each country is chosen based on the Johansen trace and maximal eigenvalues statistics.

\subsection{Testing of Weak Exogeneity}

As we already mentioned in the previous section, the main assumption of GVAR is the weak exogeneity of country-specific foreign variables. In order to check this 
Table 1: Unit Root ADF test at level

\begin{tabular}{|c|c|c|c|c|c|c|c|c|}
\hline & \multicolumn{4}{|c|}{ Level } & \multicolumn{4}{|c|}{ First Difference } \\
\hline & $y_{t}$ & miss $_{t}$ & $\exp _{t}$ & $i m p_{t}$ & $\Delta y_{t}$ & $\Delta$ miss $_{t}$ & $\Delta \exp _{t}$ & $\Delta i m p_{t}$ \\
\hline Australia & 1.7179 & -2.0584 & 2.6285 & 0.5984 & -4.1509 & -3.5554 & -1.0541 & -4.1657 \\
\hline Belgium & -0.7195 & -1.1441 & -0.9645 & -2.9957 & -5.1752 & -2.7657 & -3.2135 & -4.4062 \\
\hline Bangladesh & 0.7243 & 3.3226 & -2.2912 & 1.576900 & -3.8337 & -2.4703 & -5.0428 & -1.6862 \\
\hline Brazil & -0.9973 & -2.6474 & 3.1604 & -0.5426 & -3.2045 & -3.3176 & -1.1676 & -3.8569 \\
\hline Canada & -0.8600 & -1.4340 & 0.4132 & 0.1749 & -4.2426 & -3.4695 & -3.9539 & 0.1749 \\
\hline Switzerland & 0.8107 & -1.4722 & 4.9738 & 1.4998 & -3.9873 & -4.1014 & 2.1562 & -2.9255 \\
\hline Chile & 0.0624 & -2.4148 & 0.0591 & 0.4378 & -3.6792 & -4.6552 & -4.8658 & -4.3486 \\
\hline China & 0.9725 & -1.3911 & 0.4035 & 0.0687 & -0.3191 & -4.3384 & -4.0352 & -3.6761 \\
\hline Germany & 0.3926 & -1.0043 & -1.2063 & 0.0779 & -5.1601 & -4.8618 & -1.9592 & -4.4526 \\
\hline Spain & -1.6926 & -1.0043 & -1.2063 & 0.0779 & -2.1953 & -4.8618 & -1.9592 & -4.4526 \\
\hline France & -0.9489 & -1.4057 & -0.0461 & -1.7386 & -3.9129 & -3.8579 & -4.5651 & -1.0298 \\
\hline UK & -1.0779 & -2.2774 & 2.2420 & -1.6173 & -3.2330 & -2.3492 & -2.0883 & -1.4466 \\
\hline Hong Kong & 0.7243 & 1.1118 & 1.6632 & -0.1429 & -3.8337 & -2.8643 & -3.0547 & -3.3665 \\
\hline Indonesia & 3.1215 & 0.4695 & 1.2730 & 1.2096 & -0.7843 & -1.5651 & -3.7083 & -3.8054 \\
\hline India & 10.9493 & 1.7506 & -0.8617 & 1.051792 & 0.6339 & -6.1612 & -4.0867 & -1.5370 \\
\hline Iran, & 0.4275 & -2.8317 & 5.0101 & 4.1814 & -4.6377 & -4.7636 & 1.6837 & -0.4570 \\
\hline Italy & -2.0210 & -2.9368 & -0.6521 & -0.9840 & -3.5658 & -4.1380 & -1.7051 & -1.7867 \\
\hline Japan & -0.6859 & -2.3943 & -0.7622 & -0.9030 & -5.2412 & -4.0251 & -4.0683 & -4.1088 \\
\hline Korea, Rep. & 0.6343 & -1.7750 & -0.0517 & 0.2518 & -4.1243 & -3.6854 & -3.8946 & -4.9633 \\
\hline Morocco & -0.8199 & 0.0825 & 2.7015 & 0.9531 & -1.9181 & -7.4783 & -0.7177 & -1.9195 \\
\hline Malaysia & 2.6814 & 3.9718 & -0.0067 & 1.6069 & -1.4859 & -4.4488 & -3.4821 & -1.2400 \\
\hline Netherlands & -1.5402 & -1.4860 & 1.7373 & -0.6493 & -3.1454 & -3.8420 & -2.7525 & -1.7348 \\
\hline Oman & 1.0421 & -1.5467 & 0.0868 & -0.7210 & -3.9194 & -1.9785 & -4.3238 & -7.3188 \\
\hline Pakistan & 2.3285 & -2.0551 & -1.6776 & 1.6311 & -1.1210 & -3.2243 & -2.0219 & -3.1454 \\
\hline Peru & 2.2069 & -0.3060 & 2.8848 & 0.6022 & -1.7543 & -2.9422 & -0.7169 & -3.9843 \\
\hline Philippines & 8.3739 & 0.0532 & -0.7028 & 5.3041 & 0.5511 & -2.5512 & -4.8464 & 1.0811 \\
\hline Saudi Arabia & 1.2290 & -1.1699 & -1.6781 & -0.1623 & -3.8274 & -5.2875 & -2.0635 & -2.4032 \\
\hline Singapore & 1.2664 & -1.7053 & -1.6781 & -0.0200 & -4.3328 & -4.1813 & -2.0635 & -4.5023 \\
\hline United States & -1.0299 & -1.4441 & 0.9419 & 0.4243 & -3.1873 & -2.9206 & -3.4043 & -4.8651 \\
\hline South Africa & -0.5559 & -1.5158 & -0.6708 & -0.1644 & -3.3420 & -3.9558 & -4.6695 & -3.3645 \\
\hline
\end{tabular}

assumption, we follow the method of Dees, Mauro et al. (2007) by running the auxiliary regression. We estimate error terms for the country-specific foreign variable and jointly test the significance of error correction terms. The selection of appropriate lag length is based on the AIC and BIC criteria and residuals autocorrelation tests. Our results indicate that the weak exogeneity hypothesis could not be rejected for most of the countries, only six out of 150 tests performed reject the weak exogeneity hypothesis, as shown in Table 3.

\subsection{GVAR Results}

The coefficients of our benchmark GVAR model are estimated and generate the generalized impulse response function (GIRF) proposed by by Pesaran and Shin (1998). Our analysis mostly focuses on measuring the effect of exchange rate shocks on all other variables at a given period. Table 4 shows the contemporaneous effects of foreign variables on their domestic counterpart, also known as impact 
Table 2: Lag length and Number of Cointegrating Vectors

\begin{tabular}{|l|c|c|c|c|c|}
\hline & \multicolumn{2}{|c|}{ AIC } & \multicolumn{2}{c|}{ BIC } & CV \\
\hline Countries & $\mathbf{p}_{\mathbf{i}}$ & $\mathbf{q}_{\mathbf{i}}$ & $\mathbf{p}_{\mathrm{i}}$ & $\mathbf{q}_{\mathbf{i}}$ & \\
\hline Australia & 2 & 1 & 1 & 1 & 1 \\
\hline Belgium & 1 & 1 & 1 & 1 & 2 \\
\hline Bangladesh & 3 & 1 & 1 & 1 & 1 \\
\hline Brazil & 3 & 1 & 1 & 1 & 1 \\
\hline Canada & 3 & 1 & 2 & 1 & 3 \\
\hline Switzerland & 3 & 1 & 1 & 1 & 1 \\
\hline Chile & 3 & 1 & 1 & 1 & 3 \\
\hline China & 3 & 1 & 2 & 1 & 1 \\
\hline Germany & 3 & 1 & 3 & 1 & 3 \\
\hline Spain & 3 & 1 & 1 & 1 & 1 \\
\hline France & 3 & 1 & 2 & 1 & 3 \\
\hline United Kingdom & 3 & 1 & 1 & 1 & 1 \\
\hline Hong Kong SAR & 1 & 1 & 1 & 1 & 2 \\
\hline Indonesia & 1 & 1 & 1 & 1 & 0 \\
\hline India & 3 & 1 & 3 & 1 & 2 \\
\hline Iran, Islamic Rep. & 1 & 1 & 1 & 1 & 2 \\
\hline Italy & 3 & 1 & 3 & 1 & 3 \\
\hline Japan & 3 & 1 & 1 & 1 & 4 \\
\hline Korea, Rep. & 3 & 1 & 3 & 1 & 2 \\
\hline Morocco & 3 & 1 & 1 & 1 & 3 \\
\hline Malaysia & 3 & 1 & 1 & 1 & 1 \\
\hline Netherlands & 2 & 1 & 1 & 1 & 2 \\
\hline Oman & 1 & 1 & 1 & 1 & 1 \\
\hline Pakistan & 1 & 1 & 1 & 1 & 2 \\
\hline Peru & 3 & 1 & 1 & 1 \\
\hline Philippines & 1 & 3 & 1 & 1 \\
\hline Saudi Arabia & 3 & 1 & 1 & 3 \\
\hline Singapore & 1 & 1 & 3 \\
\hline United States & 3 & 1 & 1 & \\
\hline South Africa & 3 & 1 & 1 & 1 \\
\hline
\end{tabular}

$p_{i}$ : lag order of endogenous variable or domestic variables $q_{\mathrm{i}}$ lag order of weakly exogenous variables or foreign variables CV: cointegrating vectors

elasticities. The coefficient measures the contemporaneous variation of domestic variables caused by a $1 \%$ change in its corresponding foreign counterpart.

Table 4 shows the valuable information about the relationship between domestic variables and corresponding foreign counterpart for the sample of 30 countries. For example, $1 \%$ increase in foreign real GDP of Australia at a given period is associated with $15 \%$ in real domestic GDP of Australia in the same period. Similarly, $1 \%$ increase in foreign exports of Australia at a given period is associated with a $24 \%$ increase in domestic exports. Overall, estimated coefficients are positively associated with domestic counterparts and statistical significance for most countries.

\subsection{Impact of China's Renminbi Real Exchange Rate Shock (Undervaluation)}

The impact of the Chinese Renminbi's real exchange rate shocks on real GDP, exports and imports are shown in Table 5. It is important to stress that in our model the currency misalignment is exogenous, and shocks to currency misalignment do not affect the size of other currencies.

Table 5 shows the impact of the Chinese Renminbi's real exchange rate shock on GDP, exports and imports of the 30 sample countries. The empirical results suggest that foreign economies are affected by the undervaluation of China's Renminbi. The devaluation of the Renminbi effectively stimulates China's exports and reduced imports. The real GDP of China increases in the aftermath of positive undervaluation shocks on impact, the size is (0.06) and its decrease at minimum at the end of period 8 (0.015). In other words, the shocks have a sizeable and long-lasting effect on the real GDP of China. In the short run, the size of devaluation is high, but in long run it decreases. The response of exports and imports are different signs. More precisely, the positive sign of exports shows an increase in the size of the undervaluation of domestic currency leads to an increase in the export level. The current impact of the shock on exports is mirror (0.007), while in the long run its increases at the maximum level at the end of period 8 (0.06). On the other hand, the response of imports is negative. The results qualify the conventional trade theory. Accordingly, an increase in the undervaluation of domestic currency rise import prices and trends to reduce the volume of exports. However, the strong influence of the shock on Chinese international trade is confirmed by the response of imports. Overall, we find that the Renminbi undervaluation exerts a strong positive impact on the Chinese economy.

The response of GDP is positive in most countries like Belgium, Switzerland, Chile, Germany, Indonesia, India, Japan, Korea, Morocco, Malaysia, Netherlands, Oman, Peru, and Saudi Arabia. This confirms the leading role of China in global trade. In other words, it has a spillover effect on the economy. However, this effect is weak in the case of some other countries (for instance, the USA, the Philippine, Pakistan, Hong Kong, UK, Spain, Brazil, Bangladesh, and Australia) in the long run. In short run, the response of GDP 
Table 3: Weak Exogeneity Test

\begin{tabular}{|c|c|c|c|c|c|c|c|}
\hline & F-Stat & Crit .val & $y_{i, t}^{*}$ & miss $_{i, t}^{*}$ & $\operatorname{expi} i_{i, t}^{*}$ & $\overline{i m p_{i, t}^{*}}$ & POil $_{i, t}$ \\
\hline Australia & $F(1,22)$ & 4.3 & 0.96 & 0.89 & 2.26 & 5.27 & 0.15 \\
\hline Belgium & $F(1,19)$ & 4.36 & 3.34 & 3.45 & 1.79 & 3.61 & 2.04 \\
\hline Bangladesh & $F(1,24)$ & 4.26 & 0.86 & 2.18 & 0.99 & 2.77 & $7.42^{*}$ \\
\hline Brazil & $F(1,23)$ & 4.28 & 4.74 & 1.01 & 4.06 & 2.21 & 2.93 \\
\hline Canada & $F(1,23)$ & 4.28 & 0.74 & 0.42 & 2.63 & 1.61 & 2.36 \\
\hline Switzerland & $F(1,20)$ & 4.34 & $8.22^{*}$ & 1.09 & 2.31 & 2.76 & 3.07 \\
\hline Chile & $F(1,23)$ & 4.28 & 3.47 & 4.97 & 3.88 & 4.50 & $8.03^{*}$ \\
\hline China & $F(2,23)$ & 4.28 & 0.16 & - & 3.12 & 3.11 & 4.10 \\
\hline Germany & $F(1,23)$ & 4.28 & 0.21 & 0.00 & 2.93 & 0.93 & 0.05 \\
\hline Spain & $F(1,20)$ & 4.34 & 2.31 & 3.09 & 2.95 & 1.69 & 0.00 \\
\hline France & $F(1,23)$ & 4.28 & 1.76 & 1.40 & 0.29 & 1.46 & 2.09 \\
\hline UK & $F(1,23)$ & 4.28 & 0.07 & 4.42 & 1.38 & 1.18 & 0.34 \\
\hline Hong Kong & $F(1,23)$ & 4.28 & 0.33 & 3.04 & 0.83 & 2.36 & 0.00 \\
\hline Indonesia & $F(1,23)$ & 4.28 & 4.38 & 0.00 & 3.33 & 3.25 & $13.02^{*}$ \\
\hline India & $F(1,23)$ & 4.28 & 1.14 & 1.99 & 4.72 & 3.86 & 1.21 \\
\hline Iran & $F(1,17)$ & 4.38 & 2.67 & 0.47 & 0.08 & 1.51 & 4.76 \\
\hline Italy & $F(1,22)$ & 4.3 & 3.41 & 0.73 & 0.88 & 4.33 & 2.94 \\
\hline Japan & $F(1,23)$ & 4.28 & 0.78 & 0.00 & 0.33 & 0.00 & 2.06 \\
\hline Korea, Rep. & $F(1,23)$ & 4.28 & 3.69 & 4.23 & 0.03 & 0.18 & 8.01 \\
\hline Morocco & $F(1,23)$ & 4.28 & 2.39 & 4.63 & 3.30 & 3.44 & 0.17 \\
\hline Malaysia & $F(1,23)$ & 4.28 & 0.78 & 0.14 & 3.81 & 0.01 & 0.99 \\
\hline Netherlands & $F(1,23)$ & 4.28 & 1.19 & $10.39^{*}$ & 4.08 & 2.34 & 0.41 \\
\hline Oman & $F(1,23)$ & 4.28 & 3.20 & 0.02 & 3.56 & 5.69 & 3.06 \\
\hline Pakistan & $F(1,19)$ & 4.36 & 0.65 & 2.53 & 2.71 & 0.01 & 4.34 \\
\hline Peru & $F(1,23)$ & 4.28 & 0.59 & 1.17 & 2.87 & 0.18 & 0.12 \\
\hline Philippines & $F(1,21)$ & 4.32 & 1.97 & 2.69 & 3.38 & 2.58 & 0.00 \\
\hline Saudi Arabia & $F(1,23)$ & 4.28 & 0.07 & 4.01 & 4.18 & 1.35 & 4.60 \\
\hline Singapore & $F(1,23)$ & 4.28 & 0.33 & 1.43 & 0.03 & 0.43 & 1.77 \\
\hline United States & $F(1,23)$ & 4.28 & 0.57 & 0.12 & 2.08 & 0.81 & 2.91 \\
\hline South Africa & $F(1,20)$ & 4.34 & 0.78 & 0.15 & $7.58^{*}$ & 0.26 & 2.41 \\
\hline
\end{tabular}

Note: * indicate the statistically significant at $5 \%$

is positive in Spain, France, United Kingdom, Hong Kong, Italy, Philippines, Singapore, United States, and South Africa, but in the long run, the size of the response is mirror and negative at the end of the period 8 . The response of GDP is negative in some countries like Australia, Bangladesh, Canada and Brazil in the short-run period as well as in the long-run period. The results suggest that shocks to China's real exchange rate have no impact on GDP.
Similarly, the response of exports to real exchange rate shocks is positive both in the short-run and long-run periods in some countries like Australia, Belgium Switzerland, Germany, United Kingdom, and Japan. The positive response of exports indicates the exports of foreign countries increased with the devaluation of China's real exchange rate. This result confirms the participation of countries in global network production, most of the global economies are 
Table 4: Contemporaneous effects of foreign variables on their domestic counterparts

\begin{tabular}{|c|c|c|c|c|c|c|c|c|c|}
\hline & \multicolumn{4}{|c|}{ Domestic Variables } & \multirow[t]{2}{*}{ Country } & \multicolumn{4}{|c|}{ Domestic Variables } \\
\hline Country & $y_{t}$ & miss $_{t}$ & $\exp _{t}$ & $i m p_{t}$ & & $y_{t}$ & miss $_{t}$ & $\exp _{t}$ & $i m p_{t}$ \\
\hline \multirow[t]{2}{*}{ Australia } & 0.1559 & 0.3468 & 0.2483 & 0.2464 & Iran & 0.5685 & 2.9408 & 4.8725 & 1.6690 \\
\hline & $(0.0092)^{*}$ & $(0.0205)$ & $(0.0044)^{*}$ & $(0.0075)^{*}$ & & $(0.2090)^{*}$ & $(0.4973)^{*}$ & $(0.5599)^{\star}$ & $(0.0474)^{x}$ \\
\hline \multirow[t]{2}{*}{ Belgium } & 0.2057 & 1.4218 & 0.7546 & 0.2580 & Italy & 0.0376 & 0.4560 & 0.6269 & 0.5319 \\
\hline & $(0.0378)^{*}$ & $(0.2469)^{*}$ & $(0.1218)^{*}$ & $(0.1421)$ & & $(0.0171)^{\star}$ & $(0.0577)^{*}$ & $(0.0531)^{\star}$ & $(0.0420)^{*}$ \\
\hline \multirow[t]{2}{*}{ Bangladesh } & 0.9356 & 4.0962 & 3.3289 & 3.0511 & Japan & 0.0124 & 0.0514 & 0.0917 & 0.1013 \\
\hline & $(0.6093)^{*}$ & $(0.8517)$ & $(0.2317)^{*}$ & $(0.2037)^{*}$ & & $(0.0016)^{*}$ & $(0.0026)^{*}$ & $(0.0083)^{*}$ & $(0.0117)^{\star}$ \\
\hline \multirow[t]{2}{*}{ Brazil } & 0.1887 & 0.5926 & 0.3934 & 0.3944 & Korea, Rep. & 0.1045 & 0.1357 & 0.1337 & 0.1319 \\
\hline & $(0.0100)^{*}$ & $(0.0590)^{*}$ & $(0.0101)^{*}$ & $(0.0116)^{*}$ & & $(0.0074)^{*}$ & $(0.0036)^{*}$ & $(0.0029)^{\star}$ & $(0.0030)^{\star}$ \\
\hline \multirow[t]{2}{*}{ Canada } & 0.4004 & 0.4132 & 0.4472 & 0.4371 & Morocco & 3.9321 & 10.1019 & 6.7650 & 7.9195 \\
\hline & $(0.0359)^{*}$ & $(0.0059)^{*}$ & $(0.0080)^{*}$ & $(0.0098)^{*}$ & & $(0.8654)^{*}$ & $(1.0165)^{*}$ & $(0.3785)^{\star}$ & $(0.3831)^{*}$ \\
\hline \multirow[t]{2}{*}{ Switzerland } & 0.3016 & 1.2290 & 0.7978 & 0.8252 & Mala & 0.4231 & 0.5498 & 0.4989 & 0.4972 \\
\hline & $(0.0607)^{*}$ & $(0.0702)^{\star}$ & $(0.0363)^{*}$ & $(0.0506)^{*}$ & & $(0.0142)^{*}$ & $(0.0155)^{*}$ & $(0.0055)^{\star}$ & $(0.0052)$ \\
\hline \multirow[t]{2}{*}{ Chile } & 0.5574 & 1.4349 & 0.8979 & 0.9032 & Netherlands & 0.2129 & 0.6646 & 0.5689 & 0.5106 \\
\hline & $(0.0243)^{\star}$ & $(0.1140)^{*}$ & $(0.0173)^{*}$ & $(0.0175)^{*}$ & & $(0.0288)^{\star}$ & $(0.0290)^{*}$ & $(0.0224)^{\star}$ & $(0.0257)^{x}$ \\
\hline \multirow[t]{2}{*}{ China } & - & - & - & - & Oman & 0.4742 & 1.9542 & 1.5354 & 1.5169 \\
\hline & & & & & & $(0.1988)^{*}$ & $(0.2628)^{*}$ & $(0.0739)^{\star}$ & $(0.2839)^{x}$ \\
\hline \multirow[t]{2}{*}{ Germany } & 0.1131 & 0.1409 & 0.1543 & 0.1519 & Pakistan & 1.1524 & 2.2081 & 2.3150 & 1.7377 \\
\hline & $(0.0354)^{*}$ & $(0.0027)^{\star}$ & $(0.0035)^{*}$ & $(0.0038)^{*}$ & & $(0.0619)^{*}$ & $(0.2344)^{*}$ & $(0.2879)^{\star}$ & $(0.1106)^{*}$ \\
\hline \multirow[t]{2}{*}{ Spain } & 0.3839 & 0.7084 & 0.9049 & 0.7354 & Peru & 0.4382 & 2.0360 & 1.6887 & 1.9172 \\
\hline & $(0.0846)^{*}$ & $(0.0170)^{*}$ & $(0.0532)^{*}$ & $(0.0544)^{*}$ & & $(0.1800)^{*}$ & $(0.1067)^{*}$ & $(0.0604)^{\star}$ & \begin{tabular}{|l}
$(0.1433)^{*}$ \\
\end{tabular} \\
\hline \multirow[t]{2}{*}{ France } & 0.0643 & 0.3277 & 0.4306 & 0.4093 & Philippines & 0.7146 & 1.5420 & 1.1334 & 1.0847 \\
\hline & $(0.0271)^{\star}$ & $(0.0424)^{*}$ & $(0.0140)^{*}$ & $(0.0153)^{*}$ & & $(0.0334)^{\star}$ & $(0.1446)^{\star}$ & $(0.1716)^{\star}$ & $(0.0296)^{\star}$ \\
\hline \multirow[t]{2}{*}{ UK } & 0.0901 & 0.4489 & 0.3613 & 0.3223 & Saudi Arabia & 0.4960 & 1.2995 & 1.0988 & 0.3292 \\
\hline & $(0.0222)^{*}$ & $(0.0215)^{\star}$ & $(0.0136)^{\star}$ & $(0.0232)^{*}$ & & $(0.08451)^{\star}$ & $(0.1435)^{*}$ & $(0.0267)^{\star}$ & $(0.0100)^{\star}$ \\
\hline \multirow[t]{2}{*}{ Hong Kong } & 0.0110 & 0.0288 & 26.6646 & 0.0605 & Singapore & 0.3220 & 0.3284 & 0.3351 & 0.0524 \\
\hline & $(0.0059)^{\star}$ & $(0.0045)^{\star}$ & $(0.0675)^{*}$ & $(0.0168)^{*}$ & & $(0.0162)^{\star}$ & $(0.0036)^{*}$ & $(0.0086)^{\star}$ & $(0.0024)^{*}$ \\
\hline \multirow[t]{2}{*}{ Indonesia } & 0.4685 & 0.6622 & 0.0113 & 0.5930 & USA & 0.0157 & 0.0418 & 0.0544 & 1.1808 \\
\hline & $(0.0272)^{\star}$ & $(0.0146)^{*}$ & $(0.5724)^{*}$ & $(0.0142)^{*}$ & & $(0.0089)^{*}$ & $(0.0008)^{*}$ & $(0.0018)^{*}$ & $(0.0348)^{x}$ \\
\hline \multirow[t]{2}{*}{ India } & 0.2950 & 0.5678 & 0.4011 & 0.4059 & South Africa & 0.5831 & 1.6523 & 1.1390 & 0.6749 \\
\hline & $(0.0102)^{*}$ & $(0.0387)^{\star}$ & $(0.0128)^{*}$ & $(0.0088)^{*}$ & & $(0.0648)^{*}$ & $(0.1163)^{*}$ & $(0.0686)^{\star}$ & \begin{tabular}{|l}
$(0.0257)^{\star}$ \\
\end{tabular} \\
\hline
\end{tabular}

Note: () values show Standard error and * shows the level of statistical significance at $5 \%$

engaged in the global value chain. On the other hand, the response of exports is negative in Bangladesh, Brazil, Chile Spain, France, United Kingdom, Hong Kong Indonesia, and United States. It indicates the exports of countries decrease with increase in the size of undervaluation of China's Renminbi. The foreign countries are unable to compete in the international market with China due to the devaluation of China's currency. The results confirm that the size of the undervaluation of the Renminbi would result in the Chinese economy becoming more powerful with exchange rate adjustment reducing the trade imbalance. In other words, it confirms the leading role of China in global trade. 
Shah ABBAS, Van Chien NGUYEN, Zhu YANFU, Huu Tinh NGUYEN /

Table 5: Generalized impulse response (Chinese Renminbi undervaluation)

\begin{tabular}{|c|c|c|c|c|c|c|c|c|c|}
\hline & \multicolumn{3}{|c|}{ On GDP \% } & \multicolumn{3}{|c|}{ On Exports \% } & \multicolumn{3}{|c|}{ On Imports \% } \\
\hline & Current & 4 & 8 & Current & 4 & 8 & Current & 4 & 8 \\
\hline Australia & -0.106 & -0.009 & -0.007 & 0.049 & 0.016 & 0.009 & -0.106 & -0.039 & -0.037 \\
\hline Belgium & 0.457 & 0.045 & 0.007 & 0.104 & 0.008 & 0.006 & -0.436 & -0.059 & -0.016 \\
\hline Bangladesh & -0.169 & -0.031 & -0.021 & -0.167 & -0.047 & -0.033 & -0.009 & -0.114 & -0.065 \\
\hline Brazil & -0.042 & -0.022 & -0.009 & -0.034 & -0.026 & -0.047 & -0.008 & -0.030 & -0.021 \\
\hline Canada & -0.144 & -0.015 & -0.014 & 0.082 & -0.016 & -0.002 & -0.114 & -0.026 & -0.028 \\
\hline Switzerland & 0.072 & 0.007 & 0.006 & 0.144 & 0.017 & 0.020 & -0.073 & -0.043 & -0.049 \\
\hline Chile & 0.035 & 0.018 & 0.024 & -0.124 & -0.054 & -0.077 & -0.120 & -0.022 & -0.018 \\
\hline China & 0.060 & 0.059 & 0.015 & 0.007 & 0.145 & 0.063 & -0.056 & -0.136 & -0.094 \\
\hline Germany & 0.115 & 0.001 & 0.001 & 0.051 & 0.001 & 0.006 & 0.050 & 0.011 & 0.008 \\
\hline Spain & -0.058 & -0.004 & -0.011 & -0.046 & -0.046 & -0.055 & -0.022 & -0.017 & -0.026 \\
\hline France & 0.124 & -0.040 & -0.003 & 0.006 & -0.062 & -0.006 & -0.132 & -0.035 & -0.039 \\
\hline United Kingdom & 0.231 & -0.003 & -0.003 & 0.186 & 0.000 & 0.011 & 0.015 & -0.023 & -0.028 \\
\hline Hong Kong & 0.144 & -0.022 & -0.003 & -0.030 & -0.020 & -0.011 & 0.176 & -0.063 & -0.029 \\
\hline Indonesia & 0.062 & 0.013 & 0.007 & 0.045 & -0.033 & -0.057 & 0.032 & -0.046 & -0.056 \\
\hline India & 0.034 & 0.016 & 0.002 & -0.032 & -0.010 & -0.081 & -0.031 & -0.079 & -0.069 \\
\hline Italy & 0.096 & -0.013 & -0.019 & -0.142 & -0.027 & -0.020 & 0.001 & -0.029 & -0.037 \\
\hline Japan & 0.119 & 0.003 & 0.005 & 0.034 & 0.003 & 0.012 & 0.130 & -0.001 & -0.005 \\
\hline Korea, Rep. & 0.102 & 0.004 & 0.004 & 0.027 & -0.058 & -0.056 & -0.014 & -0.070 & -0.039 \\
\hline Morocco & 0.119 & 0.014 & 0.014 & 0.049 & 0.003 & 0.004 & -0.378 & -0.055 & -0.050 \\
\hline Malaysia & 0.084 & 0.019 & 0.001 & -0.004 & -0.008 & -0.066 & 0.037 & -0.056 & -0.047 \\
\hline Netherlands & 0.022 & 0.014 & 0.005 & -0.084 & -0.031 & -0.038 & -0.002 & 0.000 & -0.030 \\
\hline Oman & 0.041 & 0.017 & 0.015 & 0.024 & -0.037 & -0.017 & -0.062 & -0.088 & -0.058 \\
\hline Pakistan & -0.032 & -0.007 & 0.003 & 0.232 & 0.027 & 0.005 & 0.037 & -0.067 & -0.063 \\
\hline Peru & 0.075 & 0.054 & 0.131 & 0.017 & -0.145 & -0.348 & 0.141 & 0.051 & 0.156 \\
\hline Philippines & 0.157 & -0.029 & -0.035 & -0.077 & -0.015 & -0.019 & 0.088 & -0.090 & -0.095 \\
\hline Saudi Arabia & 0.158 & 0.012 & 0.002 & 0.068 & 0.015 & -0.025 & 0.113 & -0.015 & -0.019 \\
\hline Singapore & 0.107 & -0.039 & -0.021 & -0.023 & -0.056 & -0.046 & 0.062 & -0.043 & -0.025 \\
\hline United States & 0.145 & -0.005 & -0.012 & 0.059 & -0.022 & -0.020 & 0.146 & -0.023 & -0.030 \\
\hline South Africa & 0.105 & -0.027 & -0.019 & 0.061 & -0.003 & -0.037 & 0.140 & -0.031 & -0.040 \\
\hline
\end{tabular}

Overall results suggest that an increase in China's Renminbi undervaluation is more sensitive to global GDP, imports and exports. It has usually a strong impact on exports and imports of the foreign country, and stronger power to reduce the global trade imbalance. However, a positive response seems to be counterintuitive, but a negative response of imports is consistent with conventional trade theory. Theory tells us that an increase in the undervaluation of a currency increases the prices of imports and, then, tends to reduce the volume of exports.

\section{Conclusion and Implications}

China has been played an increasing and important role over the past 15 years in bilateral trade. There is a policy debate on the devaluation of RMB and its impact on the major global trade. In this paper, we investigate how China's exchange rate policy affects the global trade pattern. We investigate the impact of the Chinese exchange rate policy on its major trading partners. Using the GVAR model with a sample of 30 major trading partners, we find China's 
real exchange rate is structurally undervalued relative to other countries over the sample period. Furthermore, the long-run and short-run impact of currency misalignment undervaluation shock on GDP, exports and imports is mixed. The response of GDP and exports to China real exchange rate shock is positive, while the response of imports is negative. The overall results confirm that the undervaluation of China's exchange rate is more sensitive to global trade, and plays a strong power to reduce the global trade imbalance. The empirical results are consistent with previous studies on conventional trade theory.

The important implications of results are: First, the global vector autoregressive model provides a transmission channel that explains how the exchange rate affects the global trade and economic performance of trading patterns' economies. Second, the market-based currency policy is an important factor to increase exports and foreign direct investment. The undervaluation of China's Renminbi creates a situation to stimulate investment in China, a country where many foreign companies want to relocate their businesses.

\section{References}

Auboin, M., \& Ruta, M. (2013). The relationship between exchange rates and international trade: a literature review. World Trade Review, 12(3), 577-605.

Bahmani-Oskooee, M., \& Harvey, H. (2011). Exchange-rate volatility and industry trade between the US and Malaysia. Research in International Business and Finance, 25(2), 127155.

Bitans, M. (2004). Pass-through of exchange rates to domestic prices in east european countries and the role of economic enviroment. Working Papers 2004/04, Latvijas Banka.

Blanchard, O., \& Milesi-Ferretti, G. M. (2012). (Why) should current account balances be reduced?. IMF Economic Review, $60(1), 139-150$.

Blanchard, O. J., \& Milesi-Ferretti, G. M. (2009). Global imbalances: in midstream? Washington, DC: International Monetary Fund.

Brender, A., \& Pisani, F. (2010). Global imbalances and the collapse of globalised finance. Brussels: Centre for European Policy Studies.

Byrne, J. P., Darby, J., \& MacDonald, R. (2008). US trade and exchange rate volatility: A real sectoral bilateral analysis. Journal of Macroeconomics, 30(1), 238-259.

Cashin, P., Mohaddes, K., \& Raissi, M. (2017). China's slowdown and global financial market volatility: Is world growth losing out? Emerging Markets Review, 31, 164-175.

Choi, M. J., Kim, G.-Y., \& Lee, J. Y. (2018). An analysis of trade patterns and the effects of the real exchange rate movements in east Asia. Emerging Markets Finance and Trade, 54(7), 16351652.
Cline, W. R., \& Kim, J. (2010). Renminbi undervaluation, China's surplus, and the US trade deficit. Policy Briefs in International Economics, November, 10-20. Peterson Institute for International Economics. Available at: https:/www.piie.com/ sites/default/files/publications/pb/pb10-20.pdf

Cline, W. R., \& Williamson, J. (2011). The current currency situation. Policy Briefs in International Economics, November, 11-18. Peterson Institute for International Economics. Available at: https://www.piie.com/publications/pb/pb11-18.pdf

Dees, S., Mauro, F. D., Pesaran, M. H., \& Smith, L. V. (2007). Exploring the international linkages of the euro area: a global VAR analysis. Journal of Applied Econometrics, 22(1), 1-38.

Eichengreen, B., Hausmann, R., \& Panizza, U. (2007). Currency mismatches, debt intolerance, and the original sin: Why they are not the same and why it matters. Capital controls and capital flows in emerging economies: Policies, practices, and consequences. Chicago, IL: University of Chicago Press, 121170.

Feldkircher, M., \& Korhonen, I. (2014). The Rise of China and its Implications for Emerging Markets-Evidence from a GVAR model. Pacific Economic Review, 19(1), 61-89.

Frankel, J. A., \& Rose, A. K. (2000). Estimating the effect of currency unions on trade and output. NBER Working Paper No. 7857. National Bureau of Economic Research. DOI: $10.3386 /$ w7857

Freund, C., \& Pierola, M. D. (2012). Export superstars. Washington, DC: The World Bank.

Gangnes, B. S., Ma, A. C., \& van Assche, A. (2014). Global value chains and trade elasticities. Economics Letters, 124(3), 482486.

Greenaway, D., Kneller, R., \& Zhang, X. (2010). The effect of exchange rates on firm exports: The role of imported intermediate inputs. The World Economy, 33(8), 961-986.

Hooy, C.-W., \& Baharumshah, A. Z. (2015). Impact of Exchange Rate Volatility on Trade: Empirical Evidence for the East Asian Economies. Malaysian Journal of Economic Studies, 52(1), 7595.

Hooy, C.-W., Baharumshah, A. Z., \& Brooks, R. D. (2016). The Effect of Exchange Rate Volatility on the Nexus of Technology Sophistication and Trade Fragmentation of ASEAN5 Exports to China. Journal of Asia-Pacific Business, 17(3), 206-228.

Inoue, T., Kaya, D., \& Ohshige, H. (2015). The impact of China's slowdown on the Asia Pacific region: an application of the GVAR model. Washington, DC: The World Bank.

Irwin, S. H., \& Sanders, D. R. (2011). Index funds, financialization, and commodity futures markets. Applied Economic Perspectives and Policy, 33(1), 1-31.

Krugman, P. R., \& Obstfeld, M. (2009). International economy: theory and politics of foreign trade. Pearson Deutschland $\mathrm{GmbH}$.

Lamy, P. (2012). Global governance: From theory to practice. Journal of International Economic Law, 15(3), 721-728. 
Shah ABBAS, Van Chien NGUYEN, Zhu YANFU, Huu Tinh NGUYEN/

Journal of Asian Finance, Economics and Business Vol 7 No 8 (2020) 131-141

Leamer, E. E. (1980). The Leontief paradox, reconsidered. Journal of Political Economy, 88(3), 495-503.

Montiel, P. J., \& Ostry, J. D. (1991). Macroeconomic implications of real exchange rate targeting in developing countries. Staff Papers, 38(4), 872-900.

Mukherjee, D., \& Pozo, S. (2011). Exchange-rate volatility and trade: a semiparametric approach. Applied Economics, 43(13), 1617-1627.

Péridy, N. (2003). Exchange rate volatility, sectoral trade, and the aggregation bias. Review of World Economics, 139(3), 389-418.

Pesaran, H. H., \& Shin, Y. (1998). Generalized impulse response analysis in linear multivariate models. Economics Letters, $58(1), 17-29$.
Pesaran, M. H., Schuermann, T., \& Weiner, S. M. (2004). Modeling regional interdependencies using a global error-correcting macroeconometric model. Journal of Business \& Economic Statistics, 22(2), 129-162.

Rodrik, D. (2006). What's so special about China's exports? China \& World Economy, 14(5), 1-19.

Rodrik, D. (2008). The real exchange rate and economic growth. Brookings papers on economic activity 2008(2): 365-412.

Thanh, N. N., \& Kalirajan, K. (2005). The importance of exchange rate policy in promoting Vietnam's exports. Oxford Development Studies, 33(3-4), 511-529.

Zhang, J. X. (2012). Will RMB appreciation reduce trade deficit in the US?. Journal of the Asia Pacific Economy, 17(1), 171-187. 
